\title{
Executive's compensation, good corporate governance, ownership structure, and firm performance: a study of listed banks in Indonesia
}

\author{
Te-Kuang Chou \\ Southern Taiwan University of Science and Technology \\ Tainan, Taiwan.
}

Agung Dharmawan Buchdadi

State University of Jakarta, Indonesia

\begin{abstract}
Keywords
Indonesia, executives' compensation, ownership concentration, remuneration and nomination committee, State bank,
\end{abstract}

\begin{abstract}
This study aims to examine the relationship between executive's compensation and firm performance in the banking industry in Indonesia. This study also determines the impact of remuneration and nomination committee (RNC) on executive's compensation (EC) and firm performance. The samples are listed bank in Indonesia during 2006 - 2015. The regression uses two stage least square (2SLS) with unbalanced panel data. The findings reveal that performance on pay and pay on performance are valid in Indonesia. However, the performance is only for accounting-based performance but not for market value-based performance. Furthermore, in examining the role of remuneration and nomination committee (RNC), the findings reveal that the RNC has a negative relationship to the executives' compensation (ES). It seems the role of the RNC is preventing the overpaid of the EC. Finally, regarding the ownership structure, The state banks have the similar behavior with the main findings in this research. However, only in the state bank, the RNC has a real impact on both accounting-based performance and market value-based performance. While ownership concentration $(\mathrm{BO})$ variable which is used as dependent variables in this study reveals the possibility of the agency problems or inactive block holders condition that make ineffective monitoring role of the corporation since the findings show that the more $B O$, the more $E C$, and the worse firms performance.
\end{abstract}

Corresponding author: Agung Dharmawan Buchdadi

Email addresses for the corresponding author: abuchdadi@unj.ac.id

The first submission received: $8^{\text {th }}$ July 2017

Revised submission received: 13 th September 2017

Accepted: $16^{\text {th }}$ October 2017

\section{Introduction}

The separation of ownership and control in the firm generate the agency problems. The owners of the principals make a contract to the managers as the agent to act on behalf of the owner. Then, the problem is the agent cannot always be guaranteed to act in the best interests of the principal. To maintain the agent do in the best interest of principal, the shareholders need to spend the agency cost. There are three components of agency cost: the monitoring cost by the principal to limit not good act by the agent, the bonding cost for the agent to guarantee the agent will not do act that harm the principal, and residual cost due to some divergence between the decision made by the agent with the best decision which will maximize the wealthier of the principal (Jensen and Meckling, 1976).

In addition, two important categories of governance mechanisms in agency theory that the firm can align the interests of managers with the interests of owners are organizational monitoring mechanisms, including board structure and leadership structure; and executive incentive alignment mechanisms, including executive compensation and ownership structure (Coles, McWilliams and Sen, 2001). In term of executive compensation and firm performance research, some scholars examine the pay on performance, while the others study the performance on pay. The agency theory suggests the performance to pay relationship. In this term compensation is the reward of prior performance. In 
addition, scholars indicate that the influence of pay for performance as a motivational tool (Devers et al., 2007).

In Indonesia, the regulation regarding the good corporate governance (GCG) in banking industry begins with the development of Indonesian Banking Architecture (API) in 2004. Then, the central bank released the regulation no.4/8/PBI/2006 regarding the implementation of the GCG practices in the banking industry. The last updated regulation was released in 2013 (Chou and Buchdadi, 2017). Briefly, the regulation asked the bank to hire at least $50 \%$ of the independent board of director. In addition, the regulation asked the formation of the audit committee, risk monitoring committee, and the remuneration and nomination committee under the board of director's supervision. The bank also has to make an annual report which summarizing the number of meeting and attendance report in the annual report

It is mentioned that executive compensation is an important corporate mechanism to align the interest of managers and shareholders by increasing their working incentives and efforts (Tan, 2014). The bank has to build the remuneration and nomination committee under the board of director supervision which provides the recommendation about the remuneration for both board of directors and executives in general meeting of shareholders. The recommendation of remuneration policy need to consider on the financial performance and reserve formation of the bank, individual work performance, fairness compared to the peer group, and bank long term goal and strategic policy (Bank Indonesia, 2006).

The research examining the executives' compensation on firm performance is still attracted to many scholars (Guillet, Kucukusta and Xiao, 2012; Faria, Martins and Brandão, 2014; Crespi-Cladera and Pascual-Fuster, 2015; Alves, Barbosa and Morais, 2016; Slomka-Golebiowska and Urbanek, 2016). Perhaps, polemics on the argument regarding the executives' compensation needs more research on different condition to confirm the previous results. One argument stated that executives' compensation should be linked to past performance. In contrast, there is also the argument that the reward of the executive is for the action will benefit the firm in the long run that is not always reflected in currently observable performance (Balafas and Florackis, 2014).

For Indonesia case, only few research examining the impact of executives' compensation on firm performance. One research examining 303 firms from 2010 to 2012 noted that executives' compensation has a positive impact on firm performance which measured by return on assets (ROA) and Tobin's Q (Subekti and Sumargo, 2015). In addition, one study for non-financial firms during 2007 - 2010 found that firm performance measured by ROA, net profit margin (NPM), and earnings per share (EPS) have a positive effect and significantly to executive compensation (Mardiyati, Devi and Suherman, 2013). Moreover, A working paper examining the executives' compensation for the banking industry in Indonesia during 2007 to 2009 provides the results that return on assets (ROA), outside directors, and institutional ownership significantly affect executive compensation, but total shareholder returns do not (Suherman, Rahmawati and Buchdadi, 2011). This working paper also suggests doing further research examining the role of remuneration committee in the banking industry. Trying to develop the implementation of GCG in Indonesia especially after the updating regulation in 2013, we will combine these previous studies to examine the determinant of executives' compensation as well as the impact of executives' compensation to firm performance. It is also our intention to make a confirmation to the previous studies in developed countries as the developing countries, like Indonesia, has different political, economic, technological and cultural condition (Mulili and Wong, 2011).

\section{Literature review and hypotheses development}

In this section, we start by exploring the firm performance measurement in the banking industry. The return on assets (ROA) and Tobin's $Q$ is commonly used as the proxies of firm performance in GCG research (Klapper and Love, 2004; Basu et al., 2007; Mashayekhi and Bazaz, 2008; Munisi and Randoy, 2013; Sarpal, 2015; Abdallah and Ismail, 2016; Chou and Buchdadi, 2017). The return on assets (ROA) is an accounting-based measures performance, while the Tobin's $Q$ is market value-based measures performance. Furthermore, this study also uses non-performing loan (NPL) as the proxy of bank efficiency following the result of the recent studies that the NPL is playing an important role on the banking industry in Indonesia (Arafat et al., 2013; Chou and Buchdadi, 2016).

As it is mentioned in the introduction, this study will examine the role of the remuneration committee. Moreover, the board characteristic is a critical variable in the field of the GCG research. Board 
of directors on behalf of the shareholders do monitoring and controlling role to the manager. There are some terms regarding the board characteristics, such as: board size, board meeting, outsider/independent board, busyness board, and duality board (Liang, Xu and Jiraporn, 2013). In this research, we use the independent board of directors (IB) variable and firm size (ASSETS) as the controlling considering that many research found the positive impact of independent board of directors on firm performance (Mashayekhi and Bazaz, 2008; Black and Kim, 2012; Liang, Xu and Jiraporn, 2013; Al-Najjar, 2014; Müller, 2014; Duru, Iyengar and Zampelli, 2015; Zhu et al., 2016; Chou and Buchdadi, 2017). In addition, we also use the size of the bank following the statement that it is commonly used as the control variable (Tao and Hutchinson, 2013).

Furthermore, recent studies in good corporate governance field indicate the differences of ownership structure could make various results. In the term of government ownership, Research examining firms in gulf cooperative council (GCC) region which the firms mostly have highly concentrated ownership and also it has the relatively large government stake in listed firms found that the relationship between governance and firm performance is an increasing function of dispersed ownership and that the value addition of good governance is not necessarily maintained at high levels of ownership concentration. Furthermore, such a relationship reaches its highest level when the government or local corporations are the firm's major shareholders type of ownership (Abdallah and Ismail, 2016). In contrast, in European Union countries, government ownership is associated with lower governance quality in civil law countries. However, it is positively related to governance quality in common law countries (Borisova et al., 2012). In addition, research using samples from four Pacific Basin markets, namely, China, Hong Kong, Singapore, and Taiwan, from 2001 to 2012, the findings show that competition leads to strong payperformance sensitivity for widely-held firms, but not for family- or state-controlled firms. This result suggests that the governance role of industry competition is weakened when firms are controlled by family or the state (Ko et al., 2016). In term of ownership concentration, the previous research noted that it has a positive impact on performance as block holders will monitor the firm appropriately (Omran, 2009; Nguyen, Locke and Reddy, 2015). Meanwhile, the research using banks in 43 countries from 2002 to 2010 found that management-controlled banks take less credit risk and even less liquidity risk whereas shareholder-controlled banks encounter more liquidity risk as they pursue more interest rate risk (Chen and Lin, 2016). In this research, ownership structures in measured by shareholder independence (IND_S) and the degree of ownership concentration (OC)

\subsection{Performance to pay and pay to performance \\ Performance on pay}

It is mentioned that agency theory suggests the performance on pay relationship. In this term compensation is the reward of prior performance (Devers et al., 2007). There are some research found the positive correlation between firm performance and executives' compensation. Research in United Kingdom companies, it is found that director compensation and current shareholder returns are positively correlated. However, the paper finds little evidence of a link between directors' pay (salary and bonus) and pre-dated shareholder returns (Conyon, 1997). Moreover, In a study examining Japan corporation, the results show that current accounting-based performance has a positive impact on the current compensation. Yet, the market-based performance could not have a significant effect on the compensation (Basu et al., 2007). In addition, in China a study found a positive correlation between executives' compensation and firm performance. This study used current firm performance and also one year lagged firm performance as the independent variables (Conyon and He, 2011). Inspired by these previous researches, we propose the hypotheses as follow:

H1: The current performance will have a positive relationship with executives' compensation (EC) H2: The current performance will have a positive relationship with the next year executives' compensation (EC)

Pay on performance

It is noted that scholars examining the influence of pay on performance conceptualize compensation as a motivational tool. Then, the study uses the compensation as the predictor of the firm performance (Devers et al., 2007). This is one of the contributions of this study in developing the GCG research in Indonesia by positing the hypotheses regarding this issue as follow: 
H3: The current executives' compensation (EC) will have a positive relationship with the firm performance.

\subsection{Remuneration and nomination committee}

The previous research in Indonesia implied the future research to examine the role of the remuneration and nomination committee on executives' compensation (Suherman, Rahmawati and Buchdadi, 2011) as well as the bank performance (Chou and Buchdadi, 2017). Furthermore, we noted some research examining the committee role in GCG field. In Australia, the composition of the risk and compensation committees is positively associated with risk, which, in turn, is associated with firm performance (Tao and Hutchinson, 2013). It is also found that committee meetings have robustly significant and positive effects on efficiency (Salim, Arjomandi and Seufert, 2016). Furthermore, research on publicly listed companies across Sub-Saharan African countries the audit committee sub-indices has a positive relationship to accounting performance, but it has a negative relationship with market valuation (Munisi, Hermes and Randoy, 2014). Finally, in Indonesia the previous study found the impact of the audit committee, both the composition and the meeting to firm performance. Yet, this study could not found the role of risk committee in the banking industry (Chou and Buchdadi, 2017). Based on these researches we develop the hypotheses as follow:

H4: The numbers of remuneration and nomination committee member (RNC) will have a positive relationship with the firm performance.

H5: The numbers of remuneration and nomination committee member (RNC) will indicate a megative relationship with the executives' compensation (EC).

H6: The numbers of annual remuneration and nomination committee meeting (RNCM) will have a positive relationship with the firm performance.

H7: The numbers of annual remuneration and nomination committee meeting (RNCM) will have a negative relationship with the executives' compensation (EC).

H8: The percentage of attendance of annual remuneration and nomination committee meeting (ARNCM) will have a positive relationship with the firm performance.

H9: The percentage of attendance of annual remuneration and nomination committee meeting (ARNCM) will have a negative relationship with the executives' compensation (EC).

\section{Data and methodology}

3.1 Data

This study examines the sample from the annual reports of the listed bank in Indonesia capital market during the period 2006 to 2015 . The numbers of banks included in this study vary over the years. It had 21 banks in 2006, and it became 37 in 2015. The total number of samples are 324 banks year. We also explored the study for two different asset classes by dividing the bank in accordance with central bank regulation Indonesia (Nomor 8/4/PBI/2006 article 76; Indonesia, 2006). The first group is small banks which have asset less than IDR 10 trillion and the second group are banks which have asset more than IDR 10 trillion.

\subsection{Variables definition and model equations}

The definition of variables used in this study will present in the following table: 


\section{Table 1 Variables definition}

\begin{tabular}{|c|c|c|}
\hline Variable & Definition & Cited from \\
\hline Return on Assets (ROA) & $\begin{array}{l}\text { A ratio between the company } \\
\text { earning and its total assets }\end{array}$ & (Chou \& Buchdadi, 2016) \\
\hline $\begin{array}{l}\text { Non Performing Loan } \\
\text { (NPL) }\end{array}$ & $\begin{array}{l}\text { The amount money of loan } \\
\text { that is in default or close to } \\
\text { default. }\end{array}$ & (Chou \& Buchdadi, 2016) \\
\hline Tobin's Q & $\begin{array}{l}\text { A ratio of the market value of } \\
\text { the firm to the book-value of } \\
\text { total assets }\end{array}$ & $\begin{array}{l}\text { (Brick \& Chidambaran, } \\
\text { 2010) }\end{array}$ \\
\hline $\begin{array}{l}\text { Executive Compensation } \\
\text { (EC) }\end{array}$ & $\begin{array}{l}\text { Naturallogarithmic of sum of } \\
\text { salary, bonus, stipends, and } \\
\text { other benefits }\end{array}$ & (Bank Indonesia, 2006) \\
\hline $\begin{array}{l}\text { Remuneration and } \\
\text { Nomination Committee } \\
\text { (RNC) }\end{array}$ & $\begin{array}{l}\text { The number of Remuneration } \\
\text { and Nomination committee } \\
\text { member }\end{array}$ & (Tao \& Hutchinson, 2013) \\
\hline $\begin{array}{l}\text { The arnual meeting } \\
\text { frequency (RNCM) }\end{array}$ & $\begin{array}{l}\text { The number of annual meeting } \\
\text { of Remuneration and } \\
\text { Nomination Committee }\end{array}$ & $\begin{array}{l}\text { (Salim, Arjomandi, \& } \\
\text { Seufert, 2016; Tao \& } \\
\text { Hutchinson, 2013) }\end{array}$ \\
\hline $\begin{array}{l}\% \text { Remuneration and } \\
\text { Nomination Committee } \\
\text { Meeting Attendance } \\
\text { (ARNCM) }\end{array}$ & $\begin{array}{l}\text { The percentage of } \\
\text { Remuneration and } \\
\text { Nomination committee } \\
\text { meeting attended by the } \\
\text { member of risk committee }\end{array}$ & (Chou et al., 2013) \\
\hline Independent Board (IB) & $\begin{array}{l}\text { The natural logarithmic of } \\
\text { independent board member in } \\
\text { board of director }\end{array}$ & $\begin{array}{l}\text { Modified from (Duru, } \\
\text { Iyengar, \& Zampelli, } \\
\text { 2015) }\end{array}$ \\
\hline $\begin{array}{l}\text { Blockholders Ownership } \\
\text { (BO) }\end{array}$ & $\begin{array}{l}\text { The proportion of ordinary } \\
\text { shares held by substantial } \\
\text { shareholders with } \\
\text { shareholdine } 5 \% \text { or more }\end{array}$ & $\begin{array}{l}\text { (Samaha, Dahawy, } \\
\text { Hussainey, \& Stapleton, } \\
\text { 2012) }\end{array}$ \\
\hline LNASSET & $\begin{array}{l}\text { The natural logarithmic of the } \\
\text { assets of the bank }\end{array}$ & (Tao \& Hutchinson, 2013). \\
\hline
\end{tabular}

\subsection{Model equations}

It is mentioned that research in examining the governance-performance literature has problems regarding the econometric techniques for adjusting for all forms of endogeneity (Schultz, Tan and Walsh, 2010). Then, we applied the model equations using two stages least squares (2SLS) as follow:

$$
\begin{aligned}
& L N(E C)_{i, t}=\alpha+\beta_{1} \cdot \text { Performance }_{i, t}+\beta_{2} \cdot L N(I B)_{i, t} \\
& +\beta_{3} \cdot L N(\text { ASSET })_{i, t}+\beta_{4} \cdot B O_{i, t}+\varepsilon_{i, t} \\
& L N(E C)_{i, t+1}=\alpha+\beta_{1} \cdot \text { Performance } i_{i, t}+\beta_{2} \cdot L N(I B)_{i, t} \\
& +\beta_{3} \cdot L N(A S S E T)_{i, t}+\beta_{4} \cdot B O_{i, t}+\varepsilon_{i, t} \\
& \text { Performance }_{i, t}=\alpha+\beta_{1} \cdot L N(E C)_{i, t}+\beta_{2} \cdot L N(I B)_{i, t} \\
& +\beta_{3} \cdot L N(A S S E T)_{i, t}+\beta_{4} \cdot B O_{i, t}+\varepsilon_{i, t} \\
& L N(E C)_{i, t}=\alpha+\beta_{1} \cdot L N(R N C)_{i, t}+\beta_{2} \cdot L N(R N C M)_{i, t} \\
& +\beta_{3} \cdot L N(A R N C M)_{i, t}+\beta_{4} \cdot L N(I B)_{i, t} \\
& +\beta_{5} \cdot L N(A S S E T)_{i, t}+\beta_{6} \cdot B O_{i, t}+\varepsilon_{i, t} \\
& L N(E C)_{i, t+1}=\alpha+\beta_{1} \cdot L N(R N C)_{i, t}+\beta_{2} \cdot L N(R N C M)_{i, t} \\
& +\beta_{3} \cdot \operatorname{LN}(\text { ARNCM })_{i, t}+\beta_{4} \cdot L N(I B)_{i, t} \\
& +\beta_{5} \cdot L N(A S S E T)_{i, t}+\beta_{6} \cdot B O_{i, t}+\varepsilon_{i, t} \\
& \text { Performance }_{i, t}=\alpha+\beta_{1} \cdot L N(R N C)_{i, t}+\beta_{2} \cdot L N(R N C M)_{i, t} \\
& +\beta_{3} \cdot L N(A R N C M)_{i, t}+\beta_{4} \cdot L N(I B)_{i, t} \\
& +\beta_{5} \cdot L N(A S S E T)_{i, t}+\beta_{6} \cdot B O_{i, t}+\varepsilon_{i, t}
\end{aligned}
$$


Note: Performance are measured by ROA, Tobin's Q, and NPL. BO is the proportion of block holder's ownership.

4. Research result and discussion

\subsection{Descriptive statistics}

The descriptive statistics is presented in table 2, while the variables comparison between the small bank and the big bank is described in table 3. The mean of executive compensation (EC) in this study IDR 41,984 million (about USD 3.220 million) per year. The executives' compensation in this study includes salary, bonus, routine allowance, tantiem, and other non-natura facilities. When the banks are separated into two classes, it is noted big banks on average give bigger executives' compensation than small banks.

In addition, the bank performances are measured by ROA, Tobin's $Q$, and NPL. The average value of Tobin's $Q$ of the bank in this study is 1.088 , while the average value of NPL is 0.031 . When the banks are separated into two classes, for both variables Tobin's $Q$ and NPL, we found no significant differences among two classes and the value of both variables in each group are almost similar to the average value of the total samples. However, the average value of ROA of the total sample is 0.014 , while the average of ROA in big banks is 0.018 which is bigger than the small banks that only have ROA mean value 0.009 . Then, we could understand why the big banks deliver higher executives' compensation than small banks.

Table 2. Descriptive statistics

\begin{tabular}{lcccccc}
\hline Item & N & Mean & Median & Standard Deviation & Min & Max \\
\hline Bank Performance & & & & & \\
ROA & 303 & 0.014 & 0.014 & 0.018 & -0.129 & 0.054 \\
Tobin's Q & 210 & 1.088 & 1.037 & 0.162 & 0.827 & 2.312 \\
NPL & 306 & 0.031 & 0.022 & 0.044 & - & 0.510 \\
Good Corporate Governance Variables & & & & \\
EC & 205 & $41,984.910$ & $22,815.000$ & $55,466.972$ & 99.000 & $293,210.000$ \\
RNC & 165 & 4.145 & 4.000 & 1.594 & 1.000 & 9.000 \\
RNCM & 104 & 7.212 & 6.000 & 5.865 & 1.000 & 42.000 \\
ARNCM & 91 & 0.911 & 1.000 & 0.132 & 0.559 & 1.000 \\
Control Variables & & & & & \\
Assets & 323 & $52,864,993$ & $18,211,454$ & $152,548,629$ & 251,439 & $910,063,409$ \\
IB & 264 & 2.841 & 3.000 & 0.942 & 1.000 & 5.000 \\
Ownership Structure & & & & & \\
BO & 270 & 0.761 & 0.779 & 0.162 & 0.436 & 1.000 \\
\hline
\end{tabular}

EC and Asset are in million Rupiah

Moreover, from table 2 it is noted that the bank in Indonesia on average has 4.145 members of remuneration and nomination committee, conduct around 7.212 annual meeting, and attend $91.1 \%$ of the meeting. While the results on table 3 show that big banks have more members in remuneration and nomination committee than the small banks and also the big banks conduct more meeting than the small banks. However, the small banks attend the meeting wieldier than the big banks. It is logic that the big banks have more capability and resources to hire more committee member and conduct more meeting than the small banks.

Furthermore, the bank in Indonesia has relatively high concentration ownership. It is noted about $76 \%$ of shares are held by block holder shares. It is also noted that the small banks have more concentrated shareholders than the big banks. In addition, for indicating the state ownership we use the dummy variable method. It will have the value 1 (one) whether it has shares hold by the government (Arafat et al., 2013).

Before we do the regression analysis, we examine the Pearson's correlation test to find the multicollinearity phenomenon. The result shown in table 4 reveals that no multicollinearity among the variables. In addition, we also perform a series of test including normally distribution test, heteroscedasticity test, and autocorrelation test. Whether the autocorrelation exists in the OLS model, we 
will apply the random effect model that can overcome the problem (Murray, 2006). Then, we conducted Chow test and Housman test to examine the best model in the regression.

Table 3. Variables comparison between big bank and small bank

\begin{tabular}{|c|c|c|c|c|c|c|c|}
\hline \multirow{2}{*}{ Item } & \multicolumn{3}{|c|}{ Small Bank } & \multicolumn{3}{|c|}{ Big Bank } & \multirow{2}{*}{ t-Test } \\
\hline & $\mathrm{N}$ & Mean & St.Dev & $\mathrm{N}$ & Mean & St.Dev & \\
\hline \multicolumn{8}{|c|}{ Bank Performance } \\
\hline ROA & 127 & 0.009 & 0.020 & 176 & 0.018 & 0.015 & $-4.788^{*-* *}$ \\
\hline Tobin's $Q$ & 78 & 1.087 & 0.202 & 132 & 1.088 & 0.134 & -0.069 \\
\hline NPL & 126 & 0.033 & 0.056 & 180 & 0.030 & 0.033 & 0.400 \\
\hline \multicolumn{8}{|c|}{ Goad Corporate Governance Variables } \\
\hline $\mathrm{EC}$ & 72 & 5456 & 3558 & 133 & 61760 & 60217 & $-10.749^{*-x *}$ \\
\hline RNC & 58 & 3.276 & 0.696 & 107 & 4.617 & 1.741 & $-7.002^{*-* *}$ \\
\hline RNCM & 39 & 5.641 & 3.124 & 65 & 8.154 & 6.868 & $-2.543^{*-\pi}$ \\
\hline $\begin{array}{l}\text { ARNCM } \\
\text { Control Var }\end{array}$ & $\begin{array}{l}27 \\
a b l e s\end{array}$ & 0.962 & 0.080 & 65 & 0.889 & 0.144 & $3.084^{* x * x}$ \\
\hline Assets & 132 & $3,794,276$ & $2,647,816$ & 191 & $137,510,723$ & $179,131,345$ & $-10.315^{*-x-\pi}$ \\
\hline IB & 86 & 2.19 & 0.68 & 178 & 3.16 & 0.89 & $-9.826^{* x-3 x}$ \\
\hline \multicolumn{8}{|c|}{ Ownership Structure } \\
\hline $\mathrm{BO}$ & 95 & 0.828 & 0.130 & 175 & 0.724 & 0.166 & $5.688^{* * * *}$ \\
\hline
\end{tabular}

Table 4. Pearson's Correlation test

\begin{tabular}{|c|c|c|c|c|c|c|c|c|c|c|}
\hline Item & Assets & $\mathrm{NPL}$ & $\mathrm{ROA}$ & Tobin's Q & $\mathrm{IB}$ & EC & RNC & RNCM & ARNC & BO \\
\hline Assets & 1.000 & & & & & & & & & \\
\hline NPL & -0.065 & 1.000 & & & & & & & & \\
\hline $\mathrm{ROA}$ & 0.408 & -0.554 & 1.000 & & & & & & & \\
\hline Tobin's Q & 0.219 & -0.005 & 0.174 & 1.000 & & & & & & \\
\hline $\mathrm{IB}$ & 0.500 & -0.072 & 0.289 & 0.077 & 1.000 & & & & & \\
\hline EC & 0.869 & -0.148 & 0.405 & 0.188 & 0.550 & 1.000 & & & & \\
\hline $\mathrm{RNC}$ & 0.743 & -0.021 & 0.348 & -0.006 & 0.684 & 0.683 & 1.000 & & & \\
\hline RNCM & 0.124 & 0.216 & 0.008 & -0.197 & 0.194 & 0.079 & 0.229 & 1.000 & & \\
\hline ARNC & -0.379 & -0.094 & -0.158 & -0.087 & -0.337 & -0.255 & -0.361 & -0.257 & 1.000 & \\
\hline $\mathrm{BO}$ & -0.305 & 0.136 & -0.286 & -0.005 & -0.066 & -0.261 & -0.147 & -0.188 & 0.062 & 1.000 \\
\hline
\end{tabular}

\subsection{Discussion}

\section{Performance on pay}

The regression results for performance on pay model are presented in table 5 . The findings reveal that NPL is a very important measurement in this model. The better NPL condition, the more compensation received by the executives the current year and also the next year. This argument is more fit to the big bank as the small banks do not have a significant relationship in this model. In addition, the state banks also provide more executives' compensation in the next year regarding better NPL condition in the previous year. It is logic as on average the state banks are also the big banks. Moreover, the state banks also focus on the accounting-based profit in the current year. The better ROA will provide the better EC. In contrast, the market value does not have a significant effect on the EC. Then, this study support some previous researches, such as market value has no significant effect to compensation (Conyon, 1997; Basu et al., 2007); current accounting-based performance have a positive impact on the current compensation (Basu et al., 2007); and a positive correlation between executives' compensation and firm performance, both current firm performance and one year lagged firm performance (Conyon and He, 2011).

In addition, ownership concentration (BO) and Independent board (IB) do not have a positive impact on the current EC. However, both variables have a positive impact on EC in the next year. These condition also happens in the state bank. Probably, it is an indicator that these both monitoring variables in GCG have a vital role in controlling the EC not too overpaid. 
Table 5. Performance on pay

\begin{tabular}{|c|c|c|c|c|c|c|c|c|}
\hline \multirow[t]{2}{*}{ Variable } & \multicolumn{3}{|l|}{ LN EC } & \multicolumn{3}{|l|}{ LNEC $\mathrm{t}+1$} & \multicolumn{2}{|c|}{ State Bank } \\
\hline & Tota1 & Big & Sma11 & Tota1 & Big & Sma11 & LN EC & LNEC $t+1$ \\
\hline Model & Random & Fixed & Random & Random & Random & Random & Fixed & Random \\
\hline $\mathrm{N}$ & 140 & 92 & 48 & 111 & 72 & 39 & 37 & 31 \\
\hline Constant & -2.359 & -1.775 & -2.753 & -1.655 & -1.304 & -1.953 & -15.134 & 1.965 \\
\hline \multirow{2}{*}{ NPL } & -2.615 & -6.944 & 0.018 & -1.460 & -8.416 & 0.507 & 4.715 & -11.535 \\
\hline & $-2.465^{<4}$ & $-2.552^{* 4}$ & 0.013 & -0.875 & $-6.079^{* * x}$ & 0.571 & 0.600 & $-3.584^{* * x}$ \\
\hline \multirow{2}{*}{ ROA } & -1.453 & 6.763 & 3.595 & -2.262 & 0.743 & -0.913 & 51.100 & 4.313 \\
\hline & -0.449 & 0.797 & 0.830 & -0.493 & 0.153 & -0.337 & $1.961^{*}$ & 1.081 \\
\hline \multirow{2}{*}{ Tobin's $Q$} & 0.007 & -0.821 & -0.027 & 0.082 & 0.880 & -0.120 & -0.144 & -0.917 \\
\hline & 0.039 & -1.206 & -0.261 & 0.376 & 1.509 & -0.976 & -0.073 & -0.461 \\
\hline \multirow{2}{*}{$\mathrm{BO}$} & 0.078 & -0.366 & -0.082 & 0.125 & 0.796 & -0.553 & -0.032 & 2.246 \\
\hline & 0.825 & -0.487 & -0.303 & 0.467 & $4.086^{x 4 x}$ & -1.460 & -0.029 & $5.762^{x * x}$ \\
\hline \multirow{2}{*}{ LN IB } & 0.163 & 0.223 & -0.033 & 0.359 & 0.576 & 0.187 & -0.855 & 1.874 \\
\hline & 1.208 & 1.013 & -0.355 & $3.642^{x+4}$ & $2.297^{4 *}$ & 1.468 & -1.248 & $4.038^{-\infty \times}$ \\
\hline $\mathrm{LN}$ & 0.706 & 0.732 & 0.746 & 0.653 & 0.553 & 0.731 & 1.371 & 0.353 \\
\hline Asset & $16.674^{x+x}$ & $4.591^{\text {t*t }}$ & $13.741^{\text {*x* }}$ & $23.610^{* x *}$ & $10.865^{\text {xxx }}$ & $7.404^{4 x+}$ & $2.686^{* x}$ & $4.906^{x x x}$ \\
\hline $\mathrm{R}^{2}$ & 0.769 & 0.931 & 0.774 & 0.785 & 0.744 & 0.793 & 0.860 & 0.865 \\
\hline$A d_{j} \cdot R^{2}$ & 0.759 & 0.900 & 0.741 & 0.773 & 0.720 & 0.754 & 0.772 & 0.831 \\
\hline $\mathrm{F}$ & 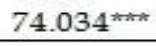 & $30.558^{* m+x}$ & $23.420^{* x+\pi x}$ & $63.549^{n-n \pi t}$ & $31.542^{\mathrm{math}}$ & $20.497^{\text {tax-k}}$ & $9.715^{\text {nknt }}$ & $25.635^{* x+k}$ \\
\hline
\end{tabular}

Bank in which the government hold some shares is a state bank. ${ }^{* * *},{ }^{* *},{ }^{*}=$ significance at the $1 \%, 5 \%$, and $10 \%$ respectively.

Pay on performance

The results shown in table 6 reveal that executives' compensation (EC) is the predictor of the current accounting-based performance, but not for market-value based performance. The EC will improve the NPL condition of the banks as well as it will improve the ROA achievement. However, it could not make the significant effect to the Tobin's $Q$. This condition also happens in the state bank. It seems the valuation of the EC regards the accounting based performance as it is commonly used in the short term compensation policy (Aggarwal, 2007).

Moreover, the ownership concentration (BO) has a negative impact on the performance. The $\mathrm{BO}$ has a negative impact on the ROA for the big bank. While, in the state bank the $\mathrm{BO}$ have a positive impact on the NPL and have a negative impact on both ROA and Tobin's $Q$. These results are in contrast with the findings in Vietnam and Singapore (Nguyen, Locke and Reddy, 2015), but support the findings in Gulf countries (Abdallah and Ismail, 2016). It is mentioned that the BO creates agency problems between majority shareholders and managers/minority shareholders, in a way that makes the performance of the firm inefficient or at best less efficient. It is also mentioned about the probability of inactive block shareholders that make ineffective monitoring role of the corporation (Abdallah and Ismail, 2016). Perhaps, it needs further research to examine the type of the BO characteristic in Indonesia to find out what are the main problems of these negative relationships.

Table 6. Pay on performance

\begin{tabular}{|c|c|c|c|c|c|c|c|c|c|c|c|c|}
\hline \multirow[t]{2}{*}{ Variable } & \multicolumn{3}{|c|}{ NPL } & \multicolumn{3}{|c|}{ ROA } & \multicolumn{3}{|c|}{ Tobin's $Q$} & \multicolumn{3}{|c|}{ State Bank } \\
\hline & $\mathrm{T}$ & B & 5 & $\mathrm{~T}$ & B & 5 & $T$ & B & 5 & NPL & ROA & $Q$ \\
\hline Model & $\mathrm{R}$ & $\mathrm{F}$ & $\mathrm{F}$ & $\mathrm{R}$ & $\mathrm{R}$ & $\mathrm{R}$ & R & F & C & $\mathbf{R}$ & R & R \\
\hline $\mathrm{N}$ & 172 & 112 & 60 & 167 & 108 & 59 & 150 & 101 & 49 & 39 & 39 & 38 \\
\hline Constant & 0.064 & 0.301 & 1.354 & -0.063 & -0.049 & -0.295 & 1.152 & 2.378 & 1.765 & 0.090 & -0.168 & 0.955 \\
\hline \multirow{2}{*}{ LNEC } & -0.031 & -0.017 & -0.054 & 0.008 & 0.004 & 0.018 & 0.013 & -0.000 & 0.016 & -0.026 & 0.004 & 0.000 \\
\hline & $-4.247^{-4 x}$ & -2.993 & -1.532 & $2.946^{* 4 *}$ & $2.489^{* 4}$ & $2.153^{* *}$ & 0.626 & -0.017 & 0.178 & $-5.444^{4 x}$ & $1.952^{*}$ & 0.051 \\
\hline \multirow{2}{*}{ во } & 0.018 & 0.031 & 0.048 & -0.016 & -0.033 & -0.015 & 0.050 & -0.205 & 0.429 & 0.123 & -0.077 & -0.180 \\
\hline & 0.692 & 0.854 & 0.616 & -1.522 & $-3.732^{2 x *}$ & -0.653 & 0.501 & -1.517 & 1.675 & $4.597^{* * *}$ & $-2.476^{* *}$ & $-1.840^{*}$ \\
\hline \multirow{2}{*}{ LNIB } & 0.002 & -0.007 & -0.000 & 0.000 & -0.002 & 0.006 & 0.000 & 0.011 & -0.004 & 0.025 & -0.015 & -0.039 \\
\hline & 0.183 & -0.510 & -0.017 & 0.156 & -0.763 & 0.647 & 0.007 & 0.295 & -0.035 & 1.379 & -1.562 & -0.577 \\
\hline \multirow{2}{*}{ LNAsset } & 0.015 & -0.006 & -0.058 & 0.000 & 0.003 & 0.010 & -0.013 & -0.063 & -0.074 & 0.001 & 0.011 & 0.014 \\
\hline & $2.404^{* *}$ & -0.711 & -1.572 & 0.232 & 1.614 & 1.101 & -0.913 & $-2.802^{* 4}$ & -0.739 & 1.402 & $1.898^{*}$ & 0.545 \\
\hline $\mathrm{R}^{2}$ & 0.124 & 0.645 & 0.769 & 0.200 & 0.286 & 0.400 & 0.003 & 0.792 & 0.073 & 0.541 & 0.620 & 0.095 \\
\hline Adj. $R^{2}$ & 0.103 & 0.531 & 0.642 & 0.180 & 0.256 & 0.355 & -0.023 & 0.715 & -0.010 & 0.487 & 0.575 & -0.014 \\
\hline F & $5.933^{*}$ & $5.664^{\text {then }}$ & $6.045^{\text {sox }}$ & $10.170^{\circ \infty}$ & $10.345^{\text {sos }}$ & $9.007^{\text {mats }}$ & 0.141 & $10.321^{\text {tot }}$ & 0.869 & 10.049 & $13.888^{\text {tom }}$ & 0.868 \\
\hline
\end{tabular}

. Note: $\mathrm{T}=$ Total Bank, $\mathrm{B}=$ Big bank, $\mathrm{S}=$ Small Bank, $\mathrm{F}=$ Fixed Effect, $\mathrm{R}=$ Random Effect, $\mathrm{C}=$ Common Effect

$* * *, * *, *=$ significance at the $1 \%, 5 \%$, and $10 \%$ respectively. 


\section{Remuneration and compensation committee}

The roles of remuneration and compensation committee are implied from the regression results on table 7 and table 8 . This committee, both the number of members and the number of meetings annually, has a negative relationship with the current year executives' compensation (EC). It means the committee will control and manage the EC avoiding the overpaid in compensation. This condition also happens among the state bank and the big bank, but not in the small bank. However, the role of the remuneration and nomination committee is not robust in determining the next year compensation. Probably it regards banks in Indonesia apply the short-term compensation policy. Moreover, the attending percentage of the committee meeting (ARNC), as well as the ownership concentration (BO), do not provide a significant impact on the EC. Then, this research broaden the previous research that found the role of committee in GCG research, such as audit committee on firm performance (Chou and Buchdadi, 2017), the composition of the risk and compensation committees on the risk which, in turn, improve the firm performance (Tao and Hutchinson, 2013), committee meetings on efficiency (Salim, Arjomandi and Seufert, 2016).

In addition, the results reveal that risk and nomination committee (RNC) does not provide a robust impact on the firm performance. It is noted only RNC among the big bank and state bank will enhance the Tobin's $Q$. The risk and nomination meeting (RNCM) also could improve the Tobin's $Q$ of the big banks. One study noted that the committee in helping monitoring function of the board of director does not necessary improving the firm value, but it does not decrease the firm value (Brick and Chidambaran, 2010). The recent study in Indonesia also reveals the similar findings with this study that risk committee does not provide a positive relationship with the firm performance (Chou and Buchdadi, 2017).

Table 7. Remuneration and nomination committee impact on compensation

\begin{tabular}{|c|c|c|c|c|c|c|c|c|}
\hline \multirow{2}{*}{ Variable } & \multicolumn{3}{|c|}{ LNEC } & \multicolumn{3}{|c|}{ LN EC $\mathrm{t}+1$} & \multicolumn{2}{|c|}{ State Bank } \\
\hline & $\mathrm{T}$ & B & 5 & $\mathrm{~T}$ & $B$ & 5 & LNEC & LNEC $t+1$ \\
\hline Model & $\bar{R}$ & $\bar{R}$ & $\bar{R}$ & $\bar{R}$ & $\bar{R}$ & R & $\bar{R}$ & $\bar{R}$ \\
\hline $\mathrm{N}$ & 83 & 59 & 24 & 50 & 36 & 14 & 24 & 16 \\
\hline Constant & -3.209 & -4.17 & 0.258 & -2.226 & -2.913 & -1.182 & -3.672 & 1.567 \\
\hline LNRNC & -0.354 & -0.425 & -0.453 & -0.044 & -0.062 & 0.122 & -0.842 & -0.842 \\
\hline & $-1.714^{*}$ & $-1.724^{*}$ & -0.611 & -0.157 & -0.731 & 0.173 & $-1.847^{*}$ & -1.109 \\
\hline LN & -0.210 & -0.234 & -0.245 & -0.145 & -0.166 & 0.077 & -0.316 & -0.451 \\
\hline RNCM & $-2.482^{* *}$ & $-2.412^{4 *}$ & -1.190 & -1.417 & $-3.495 \cdots$ & 0.654 & $-2.617^{m}$ & $-2.651^{n}$ \\
\hline ARNC & $\begin{array}{l}0.331 \\
1.059\end{array}$ & $\begin{array}{l}0.417 \\
0.200\end{array}$ & $\begin{array}{l}0.270 \\
0.252\end{array}$ & $\begin{array}{l}0.019 \\
0.048\end{array}$ & $\begin{array}{l}0.082 \\
0.285\end{array}$ & $\begin{array}{l}-1.477 \\
-2.038^{*}\end{array}$ & $\begin{array}{c}1.366 \\
2.601^{* 4}\end{array}$ & $\begin{array}{l}0.870 \\
0.937\end{array}$ \\
\hline $\mathrm{BO}$ & $\begin{array}{l}0.054 \\
0.174\end{array}$ & $\begin{array}{l}0.486 \\
0.209\end{array}$ & $\begin{array}{l}-0.611 \\
-1.279\end{array}$ & $\begin{array}{l}0.112 \\
0.291\end{array}$ & $\begin{array}{l}0.249 \\
0.320\end{array}$ & $\begin{array}{l}0.453 \\
1.788\end{array}$ & $\begin{array}{l}1.299 \\
2.106^{*}\end{array}$ & $\begin{array}{l}-0.105 \\
-0.059\end{array}$ \\
\hline LN IB & $\begin{array}{l}0.047 \\
0.261\end{array}$ & $\begin{array}{l}0.208 \\
0.979\end{array}$ & $\begin{array}{l}-0.777 \\
-1.466\end{array}$ & $\begin{array}{l}-0.052 \\
-0.183\end{array}$ & $\begin{array}{c}-0.050 \\
0.219\end{array}$ & $\begin{array}{l}-0.743 \\
-1.158\end{array}$ & $\begin{array}{c}1.873 \\
3.273^{m}\end{array}$ & $\begin{array}{c}4.207 \\
4.653^{\mathrm{4} 4}\end{array}$ \\
\hline LN Asset & $\begin{array}{c}0.793 \\
15.046^{\mathrm{k}}\end{array}$ & $\begin{array}{c}0.823 \\
10.045^{\text {ku }}\end{array}$ & $\begin{array}{c}0.653 \\
3.427^{m}\end{array}$ & $\begin{array}{c}0.729 \\
10.652^{\text {* }}\end{array}$ & $\begin{array}{c}0.761 \\
11.197\end{array}$ & $\begin{array}{c}0.739 \\
4.648\end{array}$ & $\begin{array}{c}0.676 \\
5.565\end{array}$ & $\begin{array}{l}0.341 \\
1.715\end{array}$ \\
\hline $\mathrm{R}^{2}$ & 0.824 & 0.750 & 0.587 & 0.816 & 0.671 & 0.872 & 0.827 & 0.969 \\
\hline Adj. $\mathbb{R}^{2}$ & 0.810 & 0.721 & 0.441 & 0.791 & 0.603 & 0.762 & 0.766 & 0.949 \\
\hline$F$ & $59.404^{* \infty}$ & $26.082^{*+\infty}$ & $4.035^{\star \star}$ & $31.928^{* 10}$ & $9.872^{\text {*ktk }}$ & $7.967^{* \infty}$ & $13.55^{\text {st }}$ & $48.20^{\text {*n: }}$ \\
\hline
\end{tabular}

. Note: $\mathrm{T}=$ Total Bank, $\mathrm{B}=$ Big bank, $\mathrm{S}=$ Small Bank, $\mathrm{R}=$ Random Effect

$* * *, * * *=$ significance at the $1 \%, 5 \%$, and $10 \%$ respectively. 
Table 8. Remuneration and nomination committee impact on performance

\begin{tabular}{|c|c|c|c|c|c|c|c|c|c|c|c|c|}
\hline \multirow[t]{2}{*}{ Variable } & \multicolumn{3}{|c|}{ NPL } & \multicolumn{3}{|c|}{ ROA } & \multicolumn{3}{|c|}{ Tobin's Q } & \multicolumn{3}{|c|}{ State Bank } \\
\hline & $\mathrm{T}$ & $B$ & 5 & $\mathrm{~T}$ & B & 5 & $\mathrm{~T}$ & $\mathrm{~B}$ & 5 & NPL & ROA & $Q$ \\
\hline Model & $\bar{R}$ & $\bar{R}$ & $\bar{R}$ & $\bar{R}$ & $\bar{R}$ & $\bar{R}$ & $\bar{R}$ & $\mathrm{~F}$ & $\bar{R}$ & F & $\overline{\mathrm{R}}$ & $\bar{R}$ \\
\hline $\mathrm{N}$ & 87 & 61 & 26 & 87 & 61 & 26 & 83 & 59 & 24 & 24 & 24 & 24 \\
\hline Constant & -0.013 & 0.097 & -0.074 & -0.032 & -0.057 & 0.016 & 1.191 & 1.917 & 1.056 & 0.085 & -0.221 & 0.543 \\
\hline LNRNC & $\begin{array}{l}0.012 \\
2.787^{m}\end{array}$ & $\begin{array}{c}0.028 \\
2.831\end{array}$ & $\begin{array}{l}-0.002 \\
-0.143\end{array}$ & $\begin{array}{l}0.007 \\
1.335\end{array}$ & $\begin{array}{l}0.007 \\
1.446\end{array}$ & $\begin{array}{l}0.003 \\
0.121\end{array}$ & $\begin{array}{l}0.058 \\
1.075\end{array}$ & $\begin{array}{l}0.091 \\
2.703^{4 *}\end{array}$ & $\begin{array}{l}0.353 \\
1.101\end{array}$ & $\begin{array}{l}0.002 \\
0.301\end{array}$ & $\begin{array}{l}0.007 \\
2.360^{4 *}\end{array}$ & $\begin{array}{l}0.105 \\
2.197^{4 *}\end{array}$ \\
\hline LNRNCM & $\begin{array}{l}0.004 \\
1.517\end{array}$ & $\begin{array}{l}0.008 \\
1.934^{4}\end{array}$ & $\begin{array}{l}0.000 \\
0.143\end{array}$ & $\begin{array}{l}-0.002 \\
-1.089\end{array}$ & $\begin{array}{c}-0.004 \\
-2.154^{44}\end{array}$ & $\begin{array}{l}0.008 \\
1.257\end{array}$ & $\begin{array}{l}-0.12 \\
-0.565\end{array}$ & $\begin{array}{l}0.021 \\
2.742^{4 *}\end{array}$ & $\begin{array}{l}0.088 \\
0.897\end{array}$ & $\begin{array}{l}0.004 \\
2.481^{* *}\end{array}$ & $\begin{array}{l}-0.003 \\
-13.728^{m 4}\end{array}$ & $\begin{array}{l}0.101 \\
0.727\end{array}$ \\
\hline ARNC & $\begin{array}{l}-0.004 \\
-0.530\end{array}$ & $\begin{array}{l}-0.006 \\
-0.394\end{array}$ & $\begin{array}{l}0.039 \\
1.197\end{array}$ & $\begin{array}{l}0.008 \\
1.211\end{array}$ & $\begin{array}{l}0.010 \\
1.473\end{array}$ & $\begin{array}{l}-0.029 \\
-0.865\end{array}$ & $\begin{array}{l}-0.045 \\
-0.577\end{array}$ & $\begin{array}{l}-0.055 \\
-0.803\end{array}$ & $\begin{array}{l}-0.167 \\
-0.320\end{array}$ & $\begin{array}{l}-0.005 \\
-1.272\end{array}$ & $\begin{array}{l}0.003 \\
0.389\end{array}$ & $\begin{array}{l}0.096 \\
1.445\end{array}$ \\
\hline $\mathrm{BO}$ & $\begin{array}{l}0.015 \\
1.750^{4}\end{array}$ & $\begin{array}{c}0.032 \\
2.139 * 4\end{array}$ & $\begin{array}{l}-0.012 \\
-1.097\end{array}$ & $\begin{array}{l}-0.018 \\
2.110^{-4}\end{array}$ & $\begin{array}{l}-0.033 \\
-3.014^{m}\end{array}$ & $\begin{array}{l}0.012 \\
0.757\end{array}$ & $\begin{array}{l}-0.022 \\
-0.213\end{array}$ & $\begin{array}{l}0.013 \\
0.591\end{array}$ & $\begin{array}{l}0.273 \\
0.760\end{array}$ & $\begin{array}{l}0.026 \\
1.647\end{array}$ & $\begin{array}{l}-0.067 \\
-1.856^{*}\end{array}$ & $\begin{array}{l}0.010 \\
0.129\end{array}$ \\
\hline LNIB & $\begin{array}{l}-0.024 \\
-2.268^{\alpha}\end{array}$ & $\begin{array}{l}-0.031 \\
-3.240^{4}\end{array}$ & $\begin{array}{l}-0.010 \\
-0.523\end{array}$ & $\begin{array}{l}-0.003 \\
-0.836\end{array}$ & $\begin{array}{l}-0.006 \\
-1.325\end{array}$ & $\begin{array}{l}0.019 \\
1.280\end{array}$ & $\begin{array}{l}0.051 \\
1.090\end{array}$ & $\begin{array}{l}0.074 \\
2.669^{\star *}\end{array}$ & $\begin{array}{l}0.224 \\
0.866\end{array}$ & $\begin{array}{l}0.011 \\
0.838\end{array}$ & $\begin{array}{l}-0.021 \\
-1.226\end{array}$ & $\begin{array}{l}0.005 \\
0.086\end{array}$ \\
\hline LNAsset & $\begin{array}{l}0.001 \\
0.842\end{array}$ & $\begin{array}{l}-0.006 \\
1.976^{*}\end{array}$ & $\begin{array}{l}0.005 \\
0.918\end{array}$ & $\begin{array}{l}0.002 \\
1.826^{*}\end{array}$ & $\begin{array}{c}0.005 \\
2.403^{* *}\end{array}$ & $\begin{array}{l}-0.001 \\
-0.213\end{array}$ & $\begin{array}{l}-0.009 \\
-0.637\end{array}$ & $\begin{array}{l}-0.057 \\
-1.157\end{array}$ & $\begin{array}{l}-0.049 \\
-0.544\end{array}$ & $\begin{array}{l}-0.005 \\
-0.595\end{array}$ & $\begin{array}{l}0.016 \\
2.261^{* 4}\end{array}$ & $\begin{array}{l}0.011 \\
0.515\end{array}$ \\
\hline $\mathrm{R}^{2}$ & 0.143 & 0.395 & 0.167 & 0.131 & 0.273 & 0.138 & 0.043 & 0.888 & 0.198 & 0.992 & 0.591 & 0.360 \\
\hline Adj. $R^{2}$ & 0.079 & 0.327 & -0.099 & 0.006 & 0.191 & -0.133 & -0.031 & 0.784 & -0.084 & 0.979 & 0.447 & 0.134 \\
\hline $\mathrm{F}$ & $2.235^{\star}$ & $5.879^{\star *}$ & 0.635 & $2.023^{*}$ & $3.363^{\text {nke }}$ & 0.508 & 0.579 & $8.544^{\text {sot }}$ & 0.701 & $81.215^{\text {* }}$ & $4.104^{\text {then }}$ & 1.594 \\
\hline
\end{tabular}

Note: $\mathrm{T}=$ Total Bank, $\mathrm{B}=$ Big bank, $\mathrm{S}=$ Small Bank, $\mathrm{F}=$ Fixed Effect, $\mathrm{R}=$ Random Effect, $\mathrm{C}=$ Common Effect

$* * *, * *, *=$ significance at the $1 \%, 5 \%$, and $10 \%$ respectively

\section{Conclusion}

This study aims to examine the relationship between executive's compensation and firm performance in banking industry in Indonesia. This study also determines the impact of remuneration and nomination committee on executive's compensation and firm performance. The findings regarding the performance on pay relation as it is mainly suggested in agency theory reveal that accounting-based performance, i.e., non-performing loan (NPL) and return on asset (ROA), has a positive impact on the executive's compensation (EC). However, the market-value based performance does not provide a positive impact on the EC. This finding implied that the banks in Indonesia have more attention on the accounting-based performance as it will be evaluated by the central bank annually every year (Chou and Buchdadi, 2016).

In addition, the results regarding the pay on the performance relation reveal that the EC has a positive impact on accounting-based performance, but not the market-value based performance. Then, in Indonesia the pay (executive compensation) on performance (accounting-based performance) and the performance on pay relationship have a dynamic correlation in which both correlations are valid.

Furthermore, in examining the role of remuneration and nomination committee (RNC), the findings reveal that the RNC has a negative relationship to the executives' compensation (ES). It seems the role of the RNC is preventing the overpaid of the EC. In addition, the RNC does not provide an impact on the performance. Only in the big bank class, the RNC will improve the market value of the firms. This results support the argument that the committee role monitoring the agency does not necessary improving the firm value (Brick and Chidambaran, 2010).

Finally, regarding the ownership structure, we found that the findings on the total samples are similar to the findings in the state bank. The findings reveal that the pay has a positive impact on accounting based performance, the accounting based performance also has a positive impact on executive's compensation, and the remuneration committee has a negative relationship to the executives' compensation. While, only in the state bank the remuneration and nomination committee has a good impact on both accounting-based performance and market value-based performance. In contrast, Ownership concentration (BO) variable which is used as dependent variables in this study reveals the possibility of the agency problems nor inactive block shareholders condition that make ineffective monitoring role of the corporation since the findings show that the more $\mathrm{BO}$, the more $\mathrm{EC}$, and the worse firms performance.

The limitations of this study are the number of data. We used unbalanced panel data as we cannot obtain the whole data needed in the annual report. In addition, the methodology adopted and the 
financial ratio chosen are subject to limits. Perhaps, it needs more research confirming these findings, especially data related to the remuneration and nomination committee that mostly obtained from the report after 2013. This study sheds light on the good corporate governance in emerging market that incentive to the executive and the monitoring activity are a crucial variable in governance mechanism in Indonesian banking industry.

\section{Acknowledgements}

The second author is a faculty of Economics, State University of Jakarta, Indonesia and also a recipient student in STUST Taiwan on the 3+1 Indonesian Directorate General of Higher Education (Dikti) and Elite Study in Taiwan (ESIT) Scholarship Fellowship.

The authors thank Gandung Amandani from CV. Independent Generation for preparing the raw data for this research.

\section{Reference}

Abdallah, A. A.-N. and Ismail, A. K. (2016) 'Corporate Governance Practices, Ownership Structure, and Corporate Performance in the GCC Countries', Journal of International Financial Markets, Institutions and Money. Elsevier B.V., In Press (In Press), p. In Press. doi: 10.1016/j.intfin.2016.08.004.

Aggarwal, R. K. (2007) Executive Compensation and Incentives, Handbook of Empirical Corporate Finance SET. Woodhead Publishing Limited. doi: 10.1016/B978-0-444-53265-7.50009-3.

Al-Najjar, B. (2014) 'corporate governance, tourism growth and firm performance: Evidence from publicly listed tourism firms in five Middle Eastern countries', Tourism Management. Elsevier Ltd, 42, pp. 342-351. doi: 10.1016/j.tourman.2013.09.008.

Alves, P., Barbosa, E. and Morais, P. (2016) 'Research in International Business and Finance Executive pay and performance in Portuguese listed companies', Research in International Business and Finance. Elsevier B.V., 37, pp. 184-195. doi: 10.1016/j.ribaf.2015.11.006.

Arafat, M. Y., Warokka, A., Buchdadi, A. D. and Suherman (2013) 'Banking efficiency and performance: a test of banking characteristics in an emerging market', J. for Global Business Advancement, 6(1), pp. 13-23. doi: 10.1504/JGBA.2013.053475.

Balafas, N. and Florackis, C. (2014) 'CEO compensation and future shareholder returns: Evidence from the London Stock Exchange', Journal of Empirical Finance. Elsevier B.V., 27, pp. 97-115. doi: 10.1016/j.jempfin.2013.10.011.

Bank Indonesia (2006) Peraturan Bank Indonesia Nomor 8/4/PBI/2006 Tentang Pelaksanaan Good Corporate Governance Bagi Bank Umum (Bank Indonesia Regulation No. 8/4 / PBI / 2006 on Implementation of Good Corporate Governance for Commercial Bank). Available at: http://www.bi.go.id/id/peraturan/kodifikasi/bank/Documents/GCG Complete.pdf.

Basu, S., Hwang, L. S., Mitsudome, T. and Weintrop, J. (2007) 'Corporate governance, top executive compensation and firm performance in Japan', Pacific Basin Finance Journal, 15(1), pp. 56-79. doi: 10.1016/j.pacfin.2006.05.002.

Black, B. and Kim, W. (2012) 'The effect of board structure on firm value: A multiple identification strategies approach using Korean data', Journal of Financial Economics. Elsevier, 104(1), pp. 203-226. doi: 10.1016/j.jfineco.2011.08.001.

Borisova, G., Brockman, P., Salas, J. M. and Zagorchev, A. (2012) 'Government ownership and corporate governance: Evidence from the EU', Journal of Banking and Finance. Elsevier B.V., 36(11), pp. 29172934. doi: 10.1016/j.jbankfin.2012.01.008.

Brick, I. E. and Chidambaran, N. K. (2010) 'Board meetings, committee structure, and firm value', Journal of Corporate Finance. Elsevier B.V., 16(4), pp. 533-553. doi: 10.1016/j.jcorpfin.2010.06.003.

Chen, H. J. and Lin, K. T. (2016) 'How do banks make the trade-offs among risks? The role of corporate governance', Journal of Banking and Finance. Elsevier B.V., 72, pp. S39-S69. doi: 10.1016/j.jbankfin.2016.05.010.

Chou, H. I., Chung, H. and Yin, X. (2013) 'Attendance of board meetings and company performance: Evidence from Taiwan', Journal of Banking and Finance. Elsevier B.V., 37(11), pp. 4157-4171. doi: 10.1016/j.jbankfin.2013.07.028.

Chou, T. K. and Buchdadi, A. D. (2017) 'Independent Board, Audit Committee, Risk Committee, the 
Meeting Attendance level and Its Impact on the Performance: A Study of Listed Banks in Indonesia', International Journal of Business Administration, 8(3), p. 24. doi: 10.5430/ijba.v8n3p24.

Chou, T. K. and Buchdadi, A. D. (2016) 'Bank Performance and Its Underlying Factors: A Study of Rural Banks in Indonesia', Accounting and Finance Research, 5(3), pp. 55-63. doi: 10.5430/afr.v5n3p55.

Coles, J. W., McWilliams, V. B. and Sen, N. (2001) 'An examination of the relationship of governance machanisms to performance', Journal of Management, 27(1), pp. 23-50. doi: 10.1016/S01492063(00)00085-4.

Conyon, M. J. (1997) 'Corporate governance and executive compensation', International Journal of Industrial Organization, 15(4), pp. 493-509. doi: 10.1016/S0167-7187(96)01032-6.

Conyon, M. J. and He, L. (2011) 'Executive compensation and corporate governance in China', Journal of Corporate Finance. Elsevier B.V., 17(4), pp. 1158-1175. doi: 10.1016/j.jcorpfin.2011.04.006.

Crespi-Cladera, R. and Pascual-Fuster, B. (2015) 'Executive directors' pay, networks and operating performance: The influence of ownership structure', Journal of Accounting and Public Policy, 34(2), pp. 175-203. doi: 10.1016/j.jaccpubpol.2014.09.004.

Devers, C. E., Cannella, A. A., Reilly, G. P. and Yoder, M. E. (2007) 'Executive Compensation: A Multidisciplinary Review of Recent Developments', Journal of Management, 33(6), pp. 1016-1072. doi: 10.1177/0149206307308588.

Duru, A., Iyengar, R. J. and Zampelli, E. M. (2015) 'The dynamic relationship between CEO duality and firm performance: The moderating role of board independence', Journal of Business Research. Elsevier Inc., 69(10), pp. 4269-4277. doi: 10.1016/j.jbusres.2016.04.001.

Faria, P., Martins, F. V. and Brandão, E. (2014) 'The Level of CEO Compensation for the Short and Longterm - A View on High-tech Firms', Procedia - Social and Behavioral Sciences. Elsevier B.V., 110, pp. 1023-1032. doi: 10.1016/j.sbspro.2013.12.949.

Guillet, B. D., Kucukusta, D. and Xiao, Q. (2012) 'An examination of executive compensation in the restaurant industry', International Journal of Hospitality Management. Elsevier Ltd, 31(1), pp. 86-95. doi: 10.1016/j.ijhm.2011.04.014.

Jensen, M. C. and Meckling, W. H. (1976) 'Theory of the Firm: Managerial', Journal of Financial Economics, 3, pp. 305-360. doi: http://dx.doi.org/10.1016/0304-405X(76)90026-X.

Klapper, L. F. and Love, I. (2004) 'Corporate governance, investor protection, and performance in emerging markets', Journal of Corporate Finance, 10(5), pp. 703-728. doi: 10.1016/S09291199(03)00046-4.

Ko, H. A., Tong, Y. (Jamie), Zhang, F. (Frank) and Zheng, G. (2016) 'Corporate governance, product market competition and managerial incentives: Evidence from four Pacific Basin countries', PacificBasin Finance Journal. Elsevier B.V., 40, pp. 491-502. doi: 10.1016/j.pacfin.2016.10.009.

Liang, Q., Xu, P. and Jiraporn, P. (2013) 'Board characteristics and Chinese bank performance', Journal of Banking and Finance. Elsevier B.V., 37(8), pp. 2953-2968. doi: 10.1016/j.jbankfin.2013.04.018.

Mardiyati, U., Devi, M. S. and Suherman (2013) ‘Pengaruh Kinerja Perusahaan, Corporate Governance , dan Shareholder Payout Terhadap Kompensasi Eksekutif (The Impact of firms performance, Corporate governance, and shareholder payout on executives compensation)', Jurnal Riset Manajemen Sains Indonesia (JRMSI), 4(2), pp. 167-183. Available at: http://journal.unj.ac.id/unj/index.php/jrmsi/article/view/784.

Mashayekhi, B. and Bazaz, M. S. (2008) 'Corporate Governance and Firm Performance in Iran', Journal of Contemporary Accounting \& Economics. Elsevier Ltd, 4(2), pp. 156-172. doi: 10.1016/S18155669(10)70033-3.

Mulili, B. M. and Wong, P. (2011) 'Corporate Governance Practices in Developing Countries: The Case for Kenya', International Journal of Business Administration, 2(1), p. 14. doi: 10.5430/ijba.v2n1p14.

Müller, V.-O. (2014) 'The Impact of Board Composition on the Financial Performance of FTSE100 Constituents', Procedia - Social and Behavioral Sciences. Elsevier B.V., 109, pp. 969-975. doi: 10.1016/j.sbspro.2013.12.573.

Munisi, G., Hermes, N. and Randoy, T. (2014) 'Corporate boards and ownership structure: Evidence from Sub-Saharan Africa', International Business Review. Elsevier Ltd, 23(4), pp. 785-796. doi:

10.1016/j.ibusrev.2013.12.001. 
Munisi, G. and Randoy, T. (2013) 'Corporate Governance and Company Performance across Sub-Saharan African Countries', Journal of Economics and Business. Elsevier Inc., 70, pp. 92-110. doi: 10.1016/j.jeconbus.2013.08.003.

Murray, M. P. (2006) Econometrics A Modern Introduction (chapter 16 Lecture 24), Pearson Addison-Wesley. Available at: wps.aw.com/wps/media/objects/2387/.../ch16lectr24.ppt (Accessed: 9 June 2017).

Nguyen, T., Locke, S. and Reddy, K. (2015) 'Ownership concentration and corporate performance from a dynamic perspective: Does national governance quality matter?', International Review of Financial Analysis. Elsevier Inc., 41, pp. 148-161. doi: 10.1016/j.irfa.2015.06.005.

Omran, M. (2009) 'Post-privatization corporate governance and firm performance: The role of private ownership concentration, identity and board composition', Journal of Comparative Economics. Association for Comparative Economic Studies, 37(4), pp. 658-673. doi: 10.1016/j.jce.2009.02.002.

Salim, R., Arjomandi, A. and Seufert, J. H. (2016) 'Does corporate governance affect Australian banks' performance?', Journal of International Financial Markets, Institutions and Money. Elsevier B.V., 43, pp. 113-125. doi: 10.1016/j.intfin.2016.04.006.

Samaha, K., Dahawy, K., Hussainey, K. and Stapleton, P. (2012) 'The extent of corporate governance disclosure and its determinants in a developing market: The case of Egypt', Advances in Accounting. Elsevier Ltd, 28(1), pp. 168-178. doi: 10.1016/j.adiac.2011.12.001.

Sarpal, S. (2015) 'Determinants of Corporate Board Independence: Empirical Evidence from India', Management and Labour Studies, 40(1-2), pp. 52-74. doi: 10.1177/0258042X15601533.

Schultz, E. L., Tan, D. T. and Walsh, K. D. (2010) 'Endogeneity and the corporate governance performance relation', Australian Journal of Management, 35(2), pp. 145-163. doi:

$10.1177 / 0312896210370079$.

Slomka-Golebiowska, A. and Urbanek, P. (2016) 'Corporate boards, large blockholders and executive compensation in banks: Evidence from Poland', Emerging Markets Review, 28, pp. 203-220. doi:

10.1016/j.ememar.2016.08.001.

Subekti, I. and Sumargo, D. K. (2015) 'Family Management, Executive Compensation and Financial Performance of Indonesian Listed Companies', Procedia-Social and Behavioral Sciences, 211, pp. 578584. doi: 10.1016/j.sbspro.2015.11.076.

Suherman, Rahmawati, W. and Buchdadi, A. D. (2011) Firm performance, corporate governance, and executive compensation in financial firms: Evidence from Indonesia. Available at:

https:/ / papers.ssrn.com/sol3/papers.cfm?abstract_id=1805532.

Tan, Y. (2014) 'Corporate governance in the banking sector', in Performance, Risk and Competition in the Chinese Banking Industry. Elsevier, pp. 39-64. doi: 10.1533/9781780634463.39.

Tao, N. B. and Hutchinson, M. (2013) 'Corporate governance and risk management: The role of risk management and compensation committees', Journal of Contemporary Accounting \& Economics. Elsevier Ltd, 9(1), pp. 83-99. doi: 10.1016/j.jcae.2013.03.003.

Zhu, J., Ye, K., Tucker, J. W. and Chan, K. (Johnny) C. (2016) 'Board hierarchy, independent directors, and firm value: Evidence from China', Journal of Corporate Finance. Elsevier B.V., 41, pp. 262-279. doi:

10.1016/j.jcorpfin.2016.09.009. 